\title{
PERAN PENTING SEJARAH LOKAL SEBAGAI PEMBENTUKAN KESADARAN SEJARAH SISWA
}

\author{
Oleh : Ira Lukya Safira \\ Pendidikan Sejarah
}

\begin{abstract}
Abstrak
Pada dasarnya pembelajaran sejarah merupakan ilmu yang secara sistematis mempelajari dinamika masyarakat pada masa lampau, memberikan penilaian pada masa sekarang yang hasilnya menjadi pijakan untuk masa yang akan datang. Sejarah lokal dapat menyadarkan siswa akan kekayaan kehidupan yang terjadi dalam lingkungan masyarakat sekitar, sehingga siswa dapat memahami dan memaknai peristiwa sejarah. Sejarah lokal sangat penting dalam pembelajaran sejarah selain sebagai identitas asal muasal sebuah tempat juga dapat mengetahui pola kehidupan masyarakat dan keanekaragaman budaya di berbagai daerah. Mengacu pada pembahasan tersebut, dengan mengenal sejarah lokal yang ruang lingkupnya dekat dengan tempat tinggal peserta didik akan menimbulkan suatu kebanggaan karena daerah tempat tinggal peserta didik menjadi bagian dari sejarah nasional dan akan memunculkan kesadaran nasional. Dalam implementasinya, guru dapat menyelipkan materi sejarah lokal dengan menggunakan pendekatan yang disesuaikan kurikulum. Dengan demikian, diharapkan peserta didik dapat mengetahui sejarah dan peristiwa yang terjadi di sekitar tempat tinggalnya sehingga memunculkan kesadaran sejarah.
\end{abstract}

\section{A. Pendahuluan}

Menurut (Kartodirdjo, 1993: 48) Suatu bangsa sebagai kolektivitas seperti halnya individu memiliki kepribadian yang terdiri atas serumpun ciri-ciri menjadi suatu watak. Kepribadian nasional lazimnya bersumber pada pengalaman bersama bangsa itu atau sejarahnya. Identitas seseorang pribadi dikembalikan kepada riwayatnya, maka identitas suatu bangsa berakar pada sejarah bangsa itu. Dalam hal ini, sejarah nasional fungsinya sangat fundamental untuk menciptakan kesadaran nasional yang pada gilirannya memperkokoh solidaritas nasional. Sehubungan dengan itu pelajaran sejarah nasional amat strategis fungsinya bagi pendidikan nasional. Sejarah merupakan cerita tentang pengalaman kolektif suatu komunitas atau nasional di masa lampau. Pada pribadi pengalaman membentuk kepribadian seseorang dan sekaligus menentukan identitasnya. Proses serupa terjadi pada kolektivitas, yakni pengalaman kolektifnya 
atau sejarahnyalah yang membentuk kepribadian nasional dan sekaligus identitas nasionalnya. Bangsa yang tidak mengenal sejarahnya dapat diibaratkan seorang individu yang telah kehilangan memorinya, ialah orang yang pikun atau sakit jiwa, maka dia kehilangan kepribadian atau identitasnya.

Berdasarkan pernyataan diatas, dapat ditarik kesimpulan bahwa untuk mengenal identitas suatu bangsa diperlukan pengetahuan sejarah pada umumnya, dan sejarah nasional khususnya. Sejarah nasional mencangkup secara komprehensif segala aspek kehidupan bangsa yang terwujud sebagai tindakan, perilaku, prestasi hasil usaha atau kerjanya mempertahankan kebebasan atau kedaulatannya, meningkatkan taraf hidupnya, menyelenggarakan kegiatan ekonomi, sosial, politik, religius, lagi pula menghayati kebudayaan politik beserta ideologi nasionalnya, kelangsungan masyarakat dan kulturnya. Sedangkan sejarah nasional mencakup segala lapisan sosial beserta bidang kepentingannya, subkulturnya. Sejarah nasional mengungkapkan perkembangan multietnisnya, sistem hukum adatnya, bahasa, sistem kekerabatan, kepercayaan, dan sebagainya.

Dalam menumbuhkan kesadaran sejarah pada peserta didik, pengajaran sejarah lokal dalam pembelajaran sejarah merupakan media pendidikan yang dianggap paling ampuh untuk memperkenalkan kepada peserta didik tentang proses perkembangan dan perubahan masyarakat serta keragaman sosial budaya. Selain itu dapat mengembangkan kompetensi siswa untuk berfikir secara kronologis. Dengan memahami sejarah, siswa dapat menemukan dan menumbuhkan jati diri bangsa di tengah-tengah kehidupan masyarakat dunia. Pembelajaran sejarah lokal juga membuka peluang lebih besar untuk terjadinya proses transmisi nilai kearifan lokal yang terkandung dalam budaya lokalitas setempat. Saat masuk kelas, guru sejarah mendapat tantangan yang cukup kompleks ikhwal pembelajaran sejarah lokal. Bukan saja penguasaan materi, melainkan improvisasi guru dan kejelian dalam mempertautkan materi sejarah lokal dengan kondisi riil di lapangan menjadi arena akademik yang harus ditaklukan oleh guru sejarah saat ini.

Darmawan (dalam Permana, 2020: 19) menyatakan bahwa sejarah lokal sebagai salah satu cabang dari studi sejarah sangat menarik untuk diperbincangkan terutama menyangkut batasan pengertian dan metodologi maupun dalam hak aspek pengajaran sejarah lokal di sekolah-sekolah. Hal ini sesuai dengan pendapat Brameld, (dalam Permana: 2020: 19) bahwa sasaran yang harus dicapai dalam pendidikan adalah kepemilikian atas prinsip-prinsip tentang kenyataan, kebenaran, 
dan nilai yang abadi, serta tidak terkait oleh ruang dan waktu. Adapun menurut Widja dalam bukunya yang berjudul "sejarah lokal suatu perspektif sejarah" menjelaskan bahwa sejarah lokal adalah suatu bentuk penulisan sejarah dalam lingkup yang terbatas yang meliputi suatu lokalitas tertentu. Sejarah lokal diartikan sebagai studi tentang kehidupan masyarakat atau khususnya komunitas dari suatu lingkungan sekitar (neightborhood) tertentu dalam dinamika perkembangannya terhadap berbagai aspek kehidupan manusia (Widja, 1989: hlm 13; 1991: hlm $15)$.

\section{B. Peran Penting Sejarah Lokal Sebagai Pembentukan Kesadaran Sejarah Siswa}

Menurut Mohamad Zaenal Arifin Anis (2016) fenomena kondisi pembelajaran sejarah pada masa kekinian tampaknya memunculkan permasalahan pembelajaran. Harapan mengajar sejarah sesuai dengan tujuan belajar sejarah yang tampaknya masih berupa asa, karena pengajaran sejarah masih dalam sorotan. Sorotan tersebut meliputi cara guru sejarah mengajar, materi pelajaran sejarah, sikap dan minat siswa kepada pembelajaran sejarah. Mohamad Zaenal Arifin Anis (2015) juga menegaskan bahwa sejarah adalah sebuah pembelajaran bukan warisan. Maksudnya adalah sejarah bukan hanya tentang peninggalan-peninggalan atau artefak-artefak zaman dahulu tetapi bagaimana kita memaknai hakikat suatu peristiwa sejarah bagi masa kini dan masa yang akan datang. Hal ini sejalan dengan pendapat Mohamad Zaenal Arifin Anis (2015) dalam artikelnya menjelaskan bahwa sejarah itu adalah sebuah dialog antar peristiwa masa lalu dan masa kini yang sintesanya dapat dijadikan pertimbangan untuk menghadapi persoalan kekinian yang tidak tergapai.

Namun dalam implementasi pada pembelajaran sejarah, guru cenderung menekankan pada sisi hapalan, dimana siswa diharuskan mengingat sederatan nama-nama tokoh, tanggal dan tahun sebuah peristiwa monumental. Karenanya kesadaran sejarah siswa sangat rendah. Padahal tujuan dari pembelajaran sejarah pada tataran SMA itu senidri adalah untuk mengembangkan berpikir kritis dan kreatif siswa, mengembangkan rasa ingin tahu siswa, mengembangkan kemampuan mencari, mengolah, mengemas dan mengkomunikasikan informasi serta mengembangkan semangat kebangsaan pada diri siswa. Dengan demikian, sangat diperlukan pembelajaran sejarah dengan berpikir historis yang akan memumbuhkan kesadaran historis siswa. Hal ini akan membangkitkan inspirasi dan aspirasi kepada generasi muda bagi pengabdian kepada negara dengan penuh dedikasi dan kesediaan berkorban serta dalam kehidupan sehari-harinya pun akan muncul sikap peduli dengan lingkungan sekitar, 
menghargai dan melestarikan kebudayaan yang diberikan dan memberikan kontribusi untuk lingkungan sekitar. Dengan demikian sangat jelas bahwa pelajaran sejarah tidak semata-mata memberi pengetahuan, fakta, dan kronologi. Hal ini sependapat dengan pernyataan Mohammad Zaenal Arifin Anis (2015) bahwa berpikir historis akan membawa guru dan siswa untuk mengarah pada kegiatan bagaimana belajar sejarah bukan belajar dari sejarah.

Nilai-nilai lokal sangat perlu ditekankan agar siswa tidak timpang dalam memandang sejarah. Dengan demikian, kesadaran sejarah siswa akan tumbuh jika pembelajaran sejarah dilakukan lebih intensif sesuai dengan dasar cerita dan fakta yang terjadi dilingkungan siswa. Lingkungan sejarah yang lebih kecil dari sejarah nasional dapat membantu pembelajaran sejarah terserap lebih mendalam. Karena pada idealnya pembelajaran sejarah selalu berangkat dari masalah dan fenomena-fenomena lokal agar siswa mempunyai perasaan memiliki dan membutuhkan pelajaran yang mereka terima. Oleh karena itu, dengan mengenali aspek kesejarahan dari peristiwa lokal maka siswa akan merasa memiliki kebanggaan pada wilayahnya sendiri tanpa harus kehilangan semangat menghormati kebudayaannya dan sejarah milik masyarakat lain. selain itu, dari pembelajaran sejarah lokal juga memungkinkan siswa akan lebih mempunyai ketertarikan dalam belajar sejarah dan dapat mengetahui pula bagaimana pola kehidupan masyarakat dan keanekaragaman budaya yang ada didalamnya. Hal ini disebabkan materi yang diperoleh berasal dari lingkungan dan masyarakat setempat. Seperti yang diterangkan oleh (Widya, 1991:17 dalam buku petunjuk seminar nasional 1982) bahwa dengan belajar sejarah lokal, selain bisa memperkaya perbendaharaan sejarah nasional, juga dapat memperdalam pengetahuan siswa tentang dinamika sosiokultural dari mastarakat Indonesia yang majemuk ini secara lebih intim. Dengan begitu siswa dapat menyadari bahwa terdapat berbagai corak penghadapan manusia dengan lingkungannya dan dengan sejarah.

Dalam penerapan sejarah lokal untuk mengembangkan kesadaran sejarah, siswa dapat melakukan observasi sekaligus wawancara muatan lokal yang mengakrabkan siswa dengan lingkungan sekitarnya, sehingga tentunya akan mengakomodir kebutuhan daerah. Hal ini difaktori pendekatan saintifik tidak akan maksimal bila tidak didorong oleh kopentesi guru dalam mengolah dan mengembangkan materi sejarah lokal. Guru bisa saja mengajukan beberapa pertanyaan yang mengacu pada pemahaman peserta didik terhadap sejarah lokal dan juga seberapa jauh pemahaman keberadaan peserta didik pada lingkungan sekitarnya. Seperti penjelasan (Winarti, 2020:9) siswa mendapatkan banyak contoh-contoh serta pengalaman dari 
berbagai tingkat perkembangan lingkungan masyarakatnya, termasuk situasi masa kini. Mereka juga akan lebih terdorong mengembangkan keterampilan-keterampilan khusus seperti perihal observasi, teknik bertanya atau melakukan wawancara, meyeleksi sumber, mencari fakta dan lain-lain.

Namun terdapat kelemahan dari pembelajaran ini yaitu waktunya yang sangat ketat atau terbatas dengan proses observasi hingga penulisan dalam bentuk laporan yang tentunya membutuhkan waktu yang relatif lama. Seperti yang diketahui kegiatan mengembangkan pengajaran sejarah lokal ini lebih banyak dilakukan di lapangan atau luar sekolah. Selain itu, apa yang sudah dicapai melalui pengajaran sejarah lokal sering tidak sinkron ketika siswa menghadapi ujian yang bersifat nasional, dan yang terakhir adalah kemampuan siswa dalam memberikan penilaian terhadap sumber sejarah lokal itu sendiri serta sederet kendala lainnya.

\section{Penutup}

Dalam pembelajaran sejarah, guru cenderung menekankan pada sisi hapalan, dimana siswa diharuskan mengingat sederatan nama-nama tokoh, tanggal dan tahun sebuah peristiwa monumental. Karenanya kesadaran sejarah siswa sangat rendah. Dengan demikian, sangat diperlukan pembelajaran sejarah dengan berpikir historis yang akan memumbuhkan kesadaran historis siswa. Dalam pengembangannya, guru seyogyanya mengajak peserta didik untuk lebih mempelajari sejarah yang berkaitan dengan wilayah sekitar tempat tinggal atau ruang lingkup daerahnya agar dapat memunculkan sebuah rasa kebanggaan dan timbulnya kesadaran nasional. Oleh karenanya nilai-nilai lokal Nilai-nilai lokal sangat perlu ditekankan agar siswa tidak timpang dalam memandang sejarah. Salah satu contohnya guru dapat berik kesempatan bagi peserta didik untuk menceritakan sejarah tentang daerahnya masing-masing. Dari contoh tersebut akan didapat sebuah pemahaman ataupun pandangan baru peserta didik, tidak hanya mendapat pengetahuan tetapi juga akan memunculkan berbagai inspirasi dan semangat nasionalisme sehingga peserta didik tidak akan terjerumus ke dalam generasi yang labil. 


\section{Daftara Pustaka}

Anis, M Zaenal Arifin. 2015. “Sejarah Bukan Warisan Melainkan Pembelajaran”. Prosiding Seminar Nasional dan Pertemuan Asosiasi Pendidik dan Peneliti Sejarah. Banjarmasin.

Anis, M Zaenal Arifin. 2016. “Sejarah, Kesadaran Sejarah dan Identitas Nasional”. Proceedings of the International Seminar Developing Education Based on Nationalism Values. Banjarmasin

Permana, Rahayu. 2020. "PEMBELAJARAN SEJARAH LOKAL DI SEKOLAH". Banten : Media Edukasi Indonesia.

Sartono Kartodirdjo. (1989). "Fungsi Sejarah dalam Pembangunan Nasional”, dalam Historika No.1 Tahun I. Surakarta: Program Pasca Sarjana Pendidikan Sejarah Universitas Negeri Jakarta KPK Universitas Sebelas Maret Surakarta.

Widja, I Gde. (1989). Sejarah Lokal suatu Perspektif dalam Pengembangan Sejarah. Jakarta: Departemen. 